\title{
Fabrication and Characterization of Dye-Sensitized Solar Cells for Greenhouse Application
}

\author{
Jeum-Jong Kim, ${ }^{1}$ Mangu Kang, ${ }^{1}$ Ock Keum Kwak, ${ }^{2}$ Yong-Jin Yoon, \\ Kil Sik Min, ${ }^{4}$ and Moo-Jung $\mathrm{Chu}^{1}$ \\ ${ }^{1}$ IT Materials and Components Laboratory, Electronics and Telecommunications Research Institute, \\ Daejeon 305-700, Republic of Korea \\ ${ }^{2}$ Sun Moon University, Asan-si, Chungnam 336-708, Republic of Korea \\ ${ }^{3}$ Department of Chemistry and Research Institute of Natural Science, Graduate School for Molecular Materials and Nanochemistry, \\ Gyeongsang National University, Jinju 660-701, Republic of Korea \\ ${ }^{4}$ Department of Chemistry Education, Kyungpook National University, Daegu 702-701, Republic of Korea
}

Correspondence should be addressed to Kil Sik Min; minks@knu.ac.kr and Moo-Jung Chu; mjc@etri.re.kr

Received 24 June 2014; Accepted 20 August 2014; Published 8 September 2014

Academic Editor: Mohamed Sabry A Abdel-Mottaleb

Copyright (C) 2014 Jeum-Jong Kim et al. This is an open access article distributed under the Creative Commons Attribution License, which permits unrestricted use, distribution, and reproduction in any medium, provided the original work is properly cited.

We have developed dye-sensitized solar cells using novel sensitizers with enhanced transmittance of red (625-675 nm) and blue $(425-475 \mathrm{~nm})$ wavebands to control the illumination condition in the greenhouse. Novel ruthenium bipyridyl sensitizers with general formulas $\left(\mathrm{Me}_{3} \mathrm{PhN}\right)_{4}\left[\mathrm{Ru}(\mathrm{dcbpy})_{2}(\mathrm{NCS})_{2}\right](\mathrm{JJ}-7)$ and $\left(\mathrm{Me}_{3} \mathrm{BnN}\right)_{4}\left[\mathrm{Ru}(\mathrm{dcbpy})_{2}(\mathrm{NCS})_{2}\right](\mathrm{JJ}-9)$ have been synthesized and demonstrated as efficient sensitizers in dye-sensitized solar cells for greenhouse application. Under standard AM 1.5 sunlight, the solar cell of JJ-7 using a liquid-based electrolyte exhibits a short-circuit photocurrent density of $8.49 \mathrm{~mA} / \mathrm{cm}^{2}$, an open-circuit voltage of $0.83 \mathrm{~V}$, and a fill factor of 0.71 , corresponding to an overall conversion efficiency of $4.96 \%$ on $5 \mu \mathrm{m} \mathrm{TiO}_{2}$ film. The transmittance of JJ-7 and JJ-9 shows $62.0 \%$ and $61.0 \%$ at $660 \mathrm{~nm}$ and $18.0 \%$ and $15.0 \%$ at $440 \mathrm{~nm}$ for cultivation on $5 \mu \mathrm{m} \mathrm{TiO}_{2}$ film, respectively.

\section{Introduction}

A dye-sensitized solar cell (DSSC) is an electrochemical device that uses light-absorbing dye molecules adsorbed on semiconductor nanoparticles to generate electricity from the sunlight [1-5]. Current researches on the DSSCs are focused on the development of cell materials and manufacturing techniques that give high conversion efficiency, low cost, and stability [6-8]. The preparation of dye-sensitized solar cell for greenhouse is involved in the light manipulation for plant growth and energy-saving. The light manipulation in greenhouse is very important to improve the quantity and quality of the agricultural products. The cladding materials [9-13] and artificial lights [14-20] (LED or high-pressure sodium lamps) are used to manipulate the light in greenhouse for plant growth. Until now, no dye-sensitized solar cells (DSSCs) have been applied in greenhouse for plant growth and energysaving. The most important wavebands for plant growth are the absorption peaks of chlorophyll located in the red (625$675 \mathrm{~nm}$ ) and blue ( $425-475 \mathrm{~nm}$ ) regions, respectively. The red spectrum band is known to be involved in photosynthesis and the blue band is related to the photomorphogenic and the phototropic responses of plants [21]. Therefore, dyesensitized solar cells for greenhouse can be used as technically advanced photoselective coverings that control the environmental conditions to optimize the productivity and quality of farm products and save energy. For the plant growth and energy-saving, we have focused on the development of novel sensitizers for DSSCs with enhanced transmittance of red and blue wavebands and high performance. This approach is to synthesize efficient ruthenium sensitizers through a systematic tuning of the LUMO and HOMO energy levels by introducing a ligand with a high-lying $\pi^{*}$ molecular orbital or by stabilizing the metal $t_{2 g}$ orbital. Here, we report the synthesis of novel ruthenium(II) sensitizers (JJ-7 and JJ-9) for greenhouse DSSCs and their photovoltaic performance (Figure 1). 


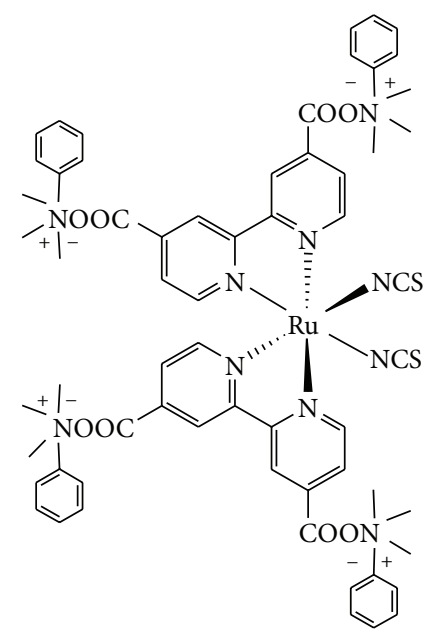

$\mathrm{JJ}-7$

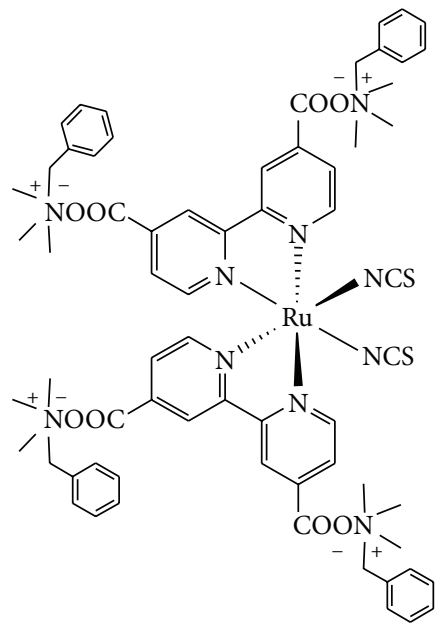

JJ-9

Figure 1: Molecular structures of JJ-7 and JJ-9.

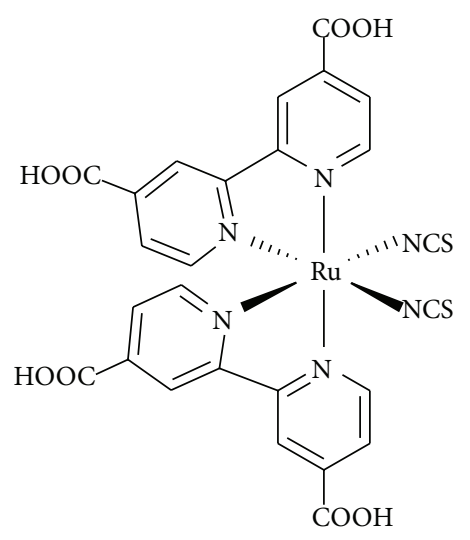

N3

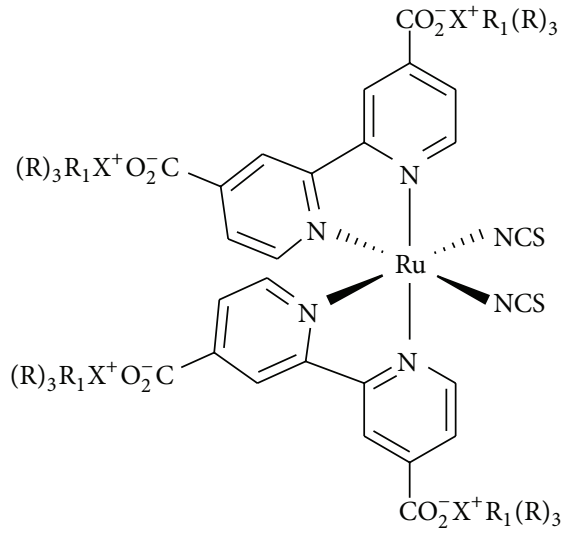

JJ-7 X $=\mathrm{N}$ and $\mathrm{R}=$ methyl, $\mathrm{R}_{1}=$ phenyl JJ-9 X $=\mathrm{N}$ and $\mathrm{R}=$ methyl, $\mathrm{R}_{1}=$ benzyl

SCHeme 1: Schematic diagram for the synthesis of sensitizers JJ-7 and JJ-9.

\section{Results and Discussion}

The synthetic route for the preparation of $\mathbf{J J - 7}$ and $\mathbf{J J}-\mathbf{9}$ is depicted in Scheme 1. JJ-7 and JJ-9 were prepared by reaction of cis-dithiocyanatobis $\left(2,2^{\prime}\right.$-bipyridine- $4,4^{\prime}$-dicarboxylate)ruthenium(II) sensitizer (N3) dye, trimethylphenylammonium hydroxide, and benzyltrimethylammonium hydroxide, respectively. The analytical and spectroscopic data of two sensitizers are consistent with the formulated structures.

Figures 2 and 3 show plant growth of greenhouse and their transmittance spectra using cladding materials. Plant 1 was grown under solar light and plants 2, 3, 4, and 5 were grown using IR cladding material, blue cladding material, green cladding material, and red cladding material, respectively (Figure 3). The UV-Vis spectrum of red cladding material displays transmittance band over $570 \mathrm{~nm}$ in visible and IR region. This band is similar to the real solar light spectrum band at red $(625-675 \mathrm{~nm})$ waveband. On the other hand, blue and green cladding materials are not transmitted at red (625$675 \mathrm{~nm}$ ) waveband (Figure 2). We have cultivated lettuce in greenhouse covered with cladding materials. The lettuce growth in red cladding material is more superior in quantity and quality to other cladding materials, but the lettuce in red cladding material does not appear red color (Figure 3). In order to obtain red color of lettuce like the real solar light, we need not only red waveband $(625-675 \mathrm{~nm})$ but also suitable blue (425-475 nm) waveband. Therefore, we have developed greenhouse dye-sensitized solar cells using novel sensitizers with transmittance at both red and blue wavebands.

Figure 4 shows the UV-Vis spectra of JJ-7 and JJ-9, together with the N719 absorption spectrum as a reference. The UV-vis spectrum of JJ-7 displays two absorption bands at 380 and $514 \mathrm{~nm}$, which are characteristic of the metal-toligand charge transfer (MLCT) bands [22, 23]. The low energy MLCT band at $514 \mathrm{~nm}$ of JJ-7 is $10 \mathrm{~nm}$ blue-shifted relative to that of N719 $(524 \mathrm{~nm})$. The band at $440 \mathrm{~nm}$ of JJ-7 exhibits 


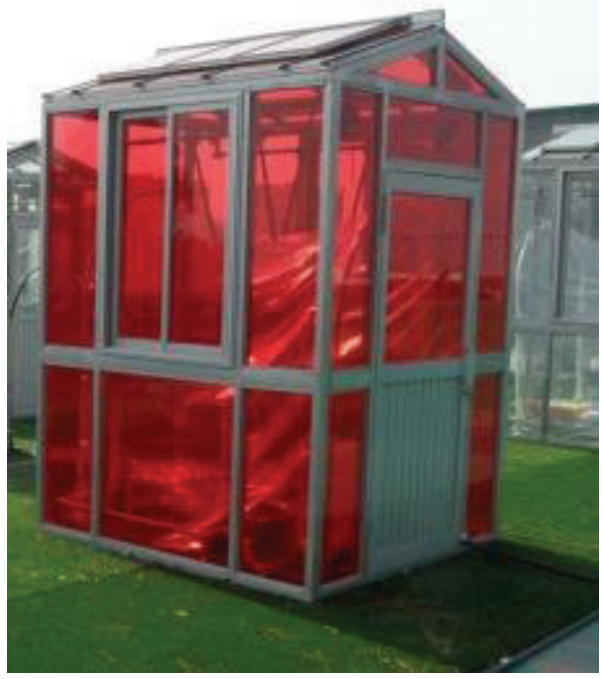

(a)

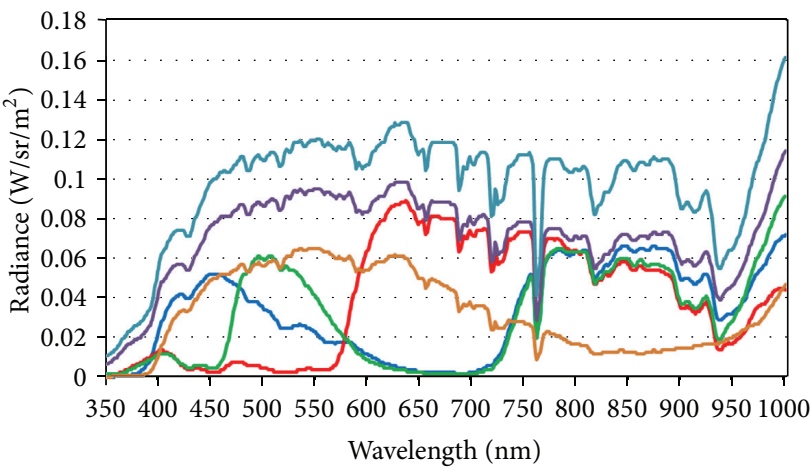

(b)

FIGURE 2: Greenhouse of plant growth and transmittance spectra under solar light (out greenhouse, dark cyan line), solar light (in greenhouse, purple line), IR cladding material (brown line), green cladding material (green line), blue cladding material (blue line), and red cladding material (red line).

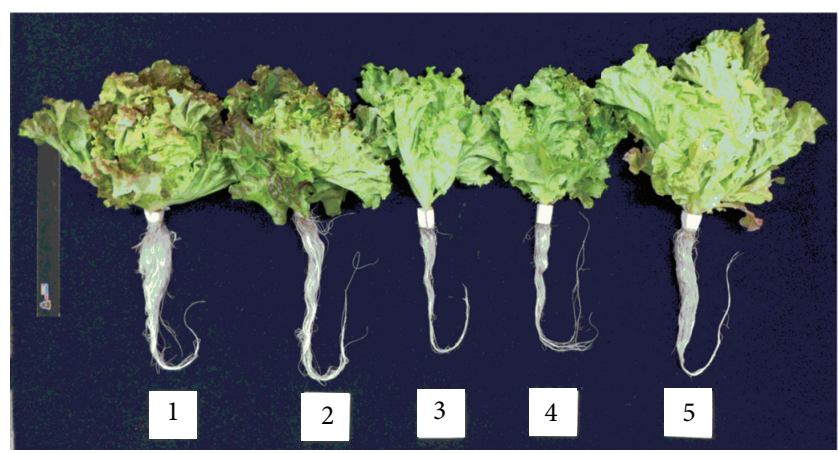

FIGURE 3: Growth of plant under solar light (1), IR cladding material (2), green cladding material (3), blue cladding material (4), and red cladding material (5).

a molar extinction coefficient of $4.5 \times 10^{3} \mathrm{M}^{-1} \mathrm{~cm}^{-1}$, which is slightly lower than that of N719 dye $\left(5.4 \times 10^{3} \mathrm{M}^{-1} \mathrm{~cm}^{-1}\right)$. The blue-shift and lower molar extinction coefficient are due to an increase in the energy of the LUMO of the ligand, causing the $\pi-\pi^{*}$ and $\mathrm{d} \pi-\pi^{*}$ transitions to occur at higher energies [24]. Also, the UV-Vis spectra of JJ-9 display two absorption bands at 380 and $514 \mathrm{~nm}$ and a molar extinction coefficient of J-9 is $4.7 \times 10^{3} \mathrm{M}^{-1} \mathrm{~cm}^{-1}$ at $440 \mathrm{~nm}$. We also observed that the sensitizers JJ-7 and JJ-9 exhibited strong luminescence maxima at $660-700 \mathrm{~nm}$ when they were excited with their MLCT bands in EtOH at $298 \mathrm{~K}$.

The ultraviolet-visible transmittance spectra of $\mathbf{~ J J}-7$ and JJ-9 adsorbed on $\mathrm{TiO}_{2}$ film are shown in Figure 5 together with the N719 transmittance spectrum as a reference. The transmittance of JJ-7 and JJ-9 on $5 \mu \mathrm{m} \mathrm{TiO}$ film exhibits $62.0 \%$ and $61.0 \%$ at red $(660 \mathrm{~nm})$ and $18.0 \%$ and $15.0 \%$ at

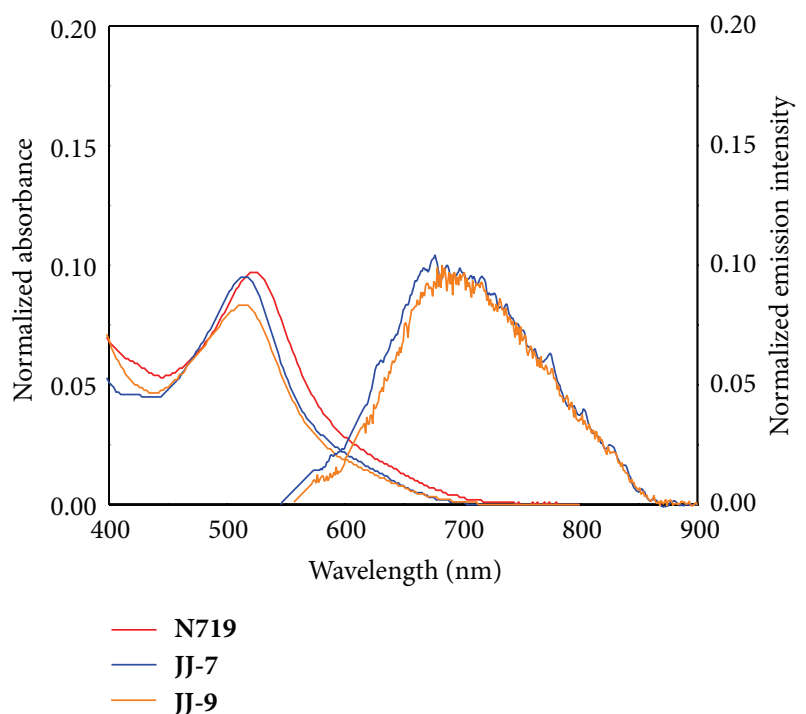

FIGURE 4: Absorption and emission spectra of JJ-7 (blue line), JJ-9 (orange line), and N719 (red line) in EtOH.

blue $(440 \mathrm{~nm})$ wavelength for plant production and quality, respectively, which is higher than the corresponding value for N719 $(48.0 \%$ at red $(660 \mathrm{~nm})$ and $7.0 \%$ at blue $(440 \mathrm{~nm})$ wavelength). Also, the transmittance of $\mathbf{J J - 7}$ and JJ-9 on $10 \mu \mathrm{m} \mathrm{TiO}$, film shows $62.9 \%$ and $60.5 \%$ at red $(660 \mathrm{~nm})$ and $7.5 \%$ and $6.3 \%$ at blue $(440 \mathrm{~nm})$ wavelength for plant production and quality, respectively, which is higher than the corresponding value for N719 $(37.9 \%$ at red $(660 \mathrm{~nm})$ and $1.5 \%$ at blue $(440 \mathrm{~nm})$ wavelength). The higher transmittance of JJ7 and JJ-9 compared with N719 is attributable to increased 


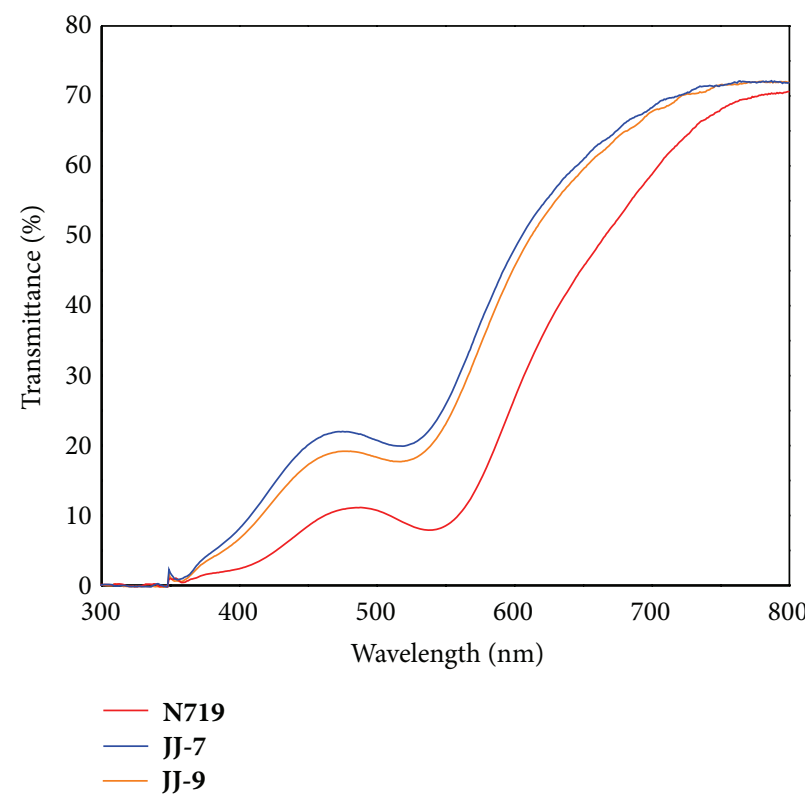

(a)

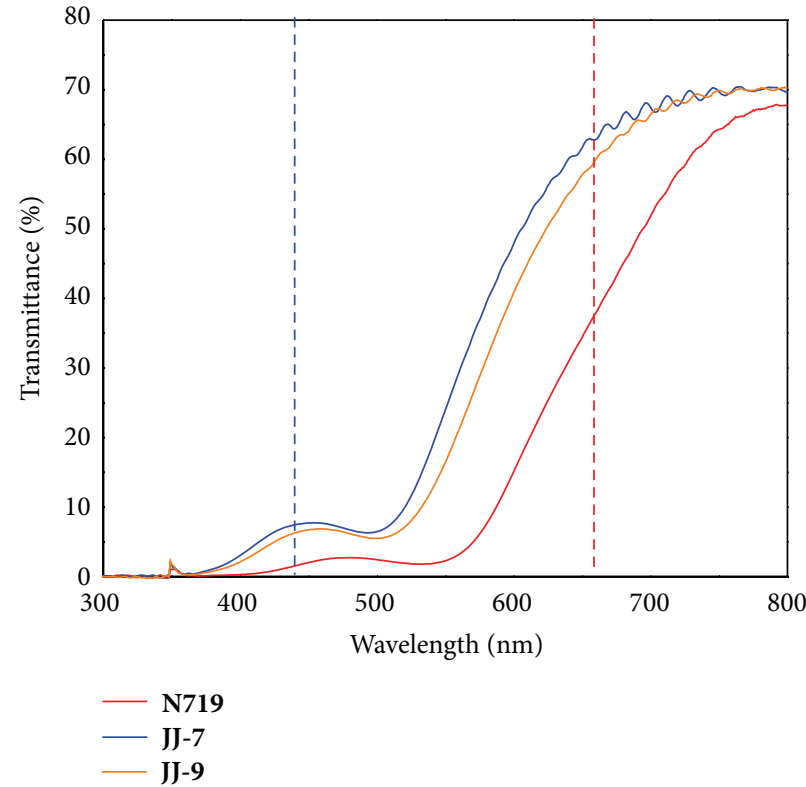

(b)

FIgURE 5: Transmittance spectra of JJ-7 (blue line), JJ-9 (orange line), and N719 (red line) (a) adsorbed on $5 \mu \mathrm{m} \mathrm{TiO}{ }_{2}$ film and (b) adsorbed on $10 \mu \mathrm{m} \mathrm{TiO}_{2}$ film.

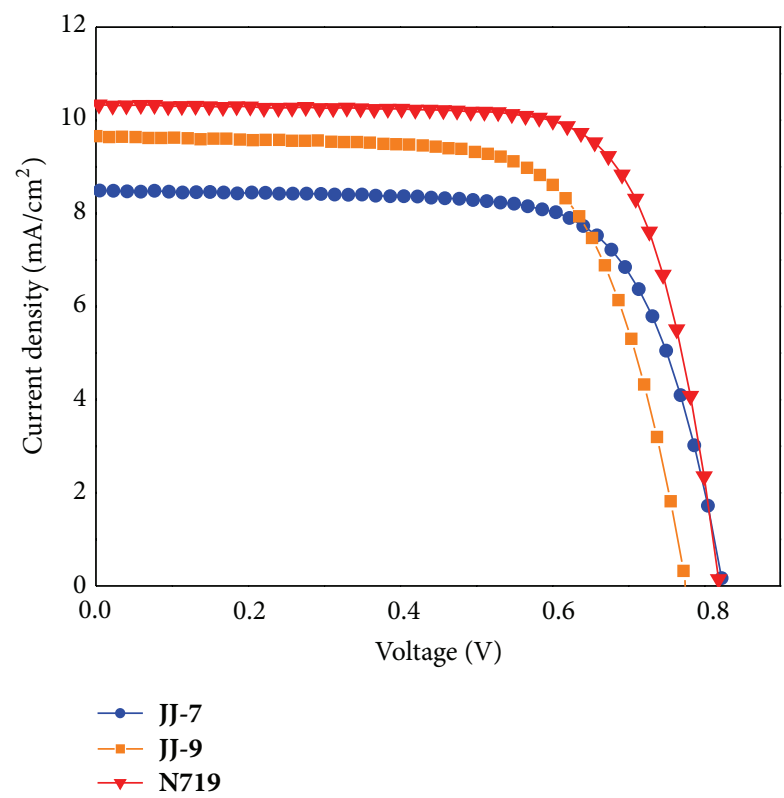

(a)

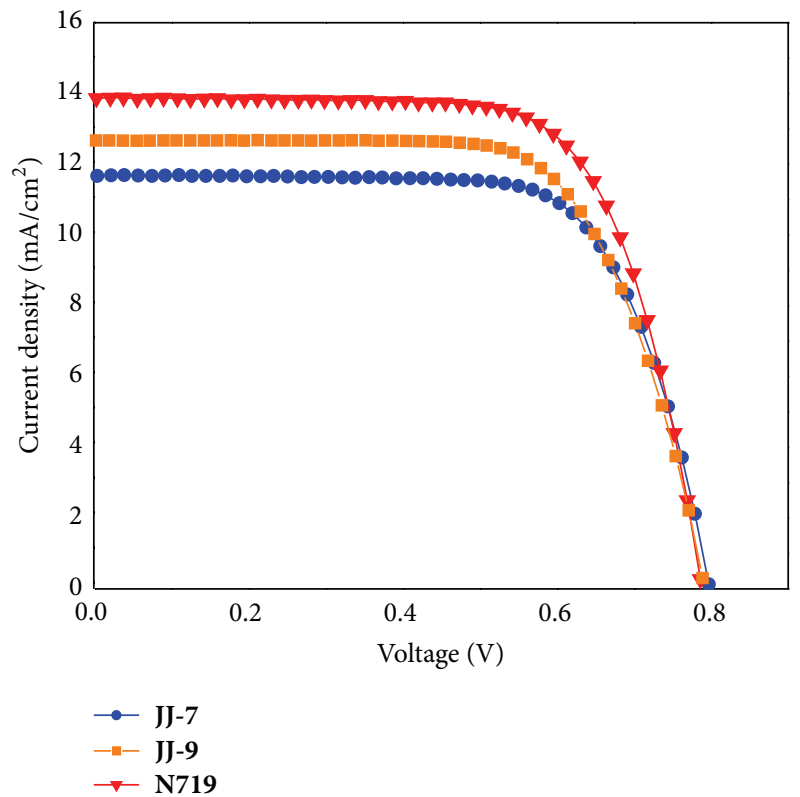

(b)

Figure 6: $J$ - $V$ curves of JJ-7 (blue line), JJ-9 (orange line), and N719 (red line) using (a) $5 \mu \mathrm{m} \mathrm{TiO}{ }_{2}$ film and (b) $10 \mu \mathrm{m} \mathrm{TiO} 2$ film.

HOMO-LUMO energy gaps by electron-withdrawing abilities in a ligand and low molar extinction coefficient.

The $J-V$ curves for the devices based on $\mathbf{J J}-7$ and $\mathrm{JJ}$ 9 are shown and compared with those of N719 in Figure 6. Under standard global AM 1.5 solar conditions, when $5 \mu \mathrm{m} \mathrm{TiO}$ film was used, the $\mathbf{J J}-7$ and $\mathbf{J J}-\mathbf{9}$ sensitized cell gave a short circuit photocurrent density $\left(J_{\mathrm{sc}}\right)$ of 8.49 and
$9.40 \mathrm{~mA} \mathrm{~cm}^{-2}$, an open circuit voltage $\left(V_{\mathrm{oc}}\right)$ of 0.83 and $0.78 \mathrm{~V}$, and a fill factor (FF) of 0.71 and 0.69 , corresponding to overall conversion efficiency $(\eta)$ of $4.96 \%$ and $5.07 \%$, respectively (Table 1). Under the same condition, the N719 sensitized cell gave a $J_{\mathrm{sc}}$ of $10.34 \mathrm{~mA} \mathrm{~cm}^{-2}$, a $V_{\mathrm{oc}}$ of $0.82 \mathrm{~V}$, and a FF of 0.74 , corresponding to $\eta$ of $6.25 \%$. When $10 \mu \mathrm{m} \mathrm{TiO}_{2}$ film was used, the $\mathbf{J J}-\mathbf{7}$ and $\mathbf{J J - 9}$ sensitized cell gave short circuit 
TABLE 1: Optical, redox, and DSSC performance parameters of dyes.

\begin{tabular}{|c|c|c|c|c|c|c|c|c|}
\hline Dye & $\begin{array}{c}\lambda_{\text {abs }}{ }^{\mathrm{a}} / \mathrm{nm} \& \\
\lambda_{\text {trans }} \mathrm{b} / \mathrm{nm}(\%)\end{array}$ & $E_{\text {redox }}{ }^{\mathrm{c}} / \mathrm{V}$ & $E_{0-0}{ }^{\mathrm{d}} / \mathrm{V}$ & $E_{\mathrm{LUMO}}{ }^{\mathrm{e}} / \mathrm{V}$ & $\begin{array}{c}J_{\mathrm{sc}}\left(\mathrm{mA} \mathrm{cm}^{-2}\right) \\
(5 / 10 \mu \mathrm{m})\end{array}$ & $\begin{array}{c}V_{\mathrm{oc}}(\mathrm{V}) \\
(5 / 10 \mu \mathrm{m})\end{array}$ & $\begin{array}{c}\mathrm{FF} \\
(5 / 10 \mu \mathrm{m})\end{array}$ & $\begin{array}{c}\eta^{\mathrm{f}}(\%) \\
(5 / 10 \mu \mathrm{m})\end{array}$ \\
\hline $\mathrm{JJ}-7$ & $\begin{array}{c}380,514 \& 440(18) \\
660(62)\end{array}$ & 1.07 & 2.08 & -1.01 & $8.49 / 11.68$ & $0.83 / 0.80$ & $0.71 / 0.71$ & $4.96 / 6.58$ \\
\hline $\mathrm{JJ}-9$ & $\begin{array}{c}380,514 \& 440(15) \\
660(61)\end{array}$ & 1.03 & 2.06 & -1.03 & $9.40 / 12.62$ & $0.78 / 0.80$ & $0.69 / 0.69$ & $5.07 / 6.93$ \\
\hline N719 & $\begin{array}{c}382,524 \& 440(7) \\
660(48)\end{array}$ & & $2.03^{\mathrm{g}}\left(1.97^{\mathrm{h}}\right)$ & & $10.34 / 13.87$ & $0.82 / 0.79$ & $0.74 / 0.70$ & $6.25 / 7.67$ \\
\hline
\end{tabular}

${ }^{\mathrm{a}}$ Absorption spectra were measured in EtOH solution. ${ }^{\mathrm{b}}$ Transmittance spectra were measured on 1-layer $\mathrm{TiO}_{2}$ film. ${ }^{\mathrm{c}}$ Redox potential of dyes on TiO ${ }_{2}$ was measured in $\mathrm{CH}_{3} \mathrm{CN}$ with $0.1 \mathrm{M}\left(n-\mathrm{C}_{4} \mathrm{H}_{9}\right)_{4} \mathrm{NPF}_{6}$ as a scan rate of $100 \mathrm{mV} \mathrm{s}^{-1}$ ( $v$ s. NHE). ${ }^{\mathrm{d}} E_{0-0}$ values were estimated from the onset of absorption spectrum. ${ }^{\mathrm{e}} E_{\mathrm{LUMO}}$ was calculated by $E_{\mathrm{ox}}-E_{0-0} .{ }^{\mathrm{f}}$ Performances of DSSCs were measured with $0.18 \mathrm{~cm}^{2}$ working area. Electrolyte: $0.6 \mathrm{M} \mathrm{DMPImI}, 0.05 \mathrm{MI}, 0.5 \mathrm{M} \mathrm{TBP}$, and $0.1 \mathrm{M} \mathrm{LiI}$ in acetonitrile. ${ }^{\mathrm{g}}$ Energy level calculated by experiment. ${ }^{\mathrm{h}}$ Energy level calculated at the B3LYP/3-21 G.

photocurrent density $\left(J_{\mathrm{sc}}\right)$ of 11.68 and $12.62 \mathrm{~mA} \mathrm{~cm}^{-2}$, an open circuit voltage $\left(V_{\text {oc }}\right)$ of 0.80 and $0.80 \mathrm{~V}$, and a fill factor (FF) of 0.71 and 0.69 , corresponding to overall conversion efficiency $(\eta)$ of $6.58 \%$ and $6.93 \%$, respectively (Table 1 ). Under the same condition, the N719 sensitized cell gave a $J_{\text {sc }}$ of $13.87 \mathrm{~mA} \mathrm{~cm}^{-2}$, a $V_{\text {oc }}$ of $0.79 \mathrm{~V}$, and a FF of 0.70 , corresponding to $\eta$ of $7.67 \%$. A slightly lower $J_{\text {sc }}$ of $\mathrm{JJ}-7$ and JJ-9 relative to $\mathbf{N 7 1 9}$ can be related to the increase of transmittance and the sparse packing of the $\mathbf{J J}-7$ and $\mathbf{~ J -}$ 9 monolayers on the $\mathrm{TiO}_{2}$ electrodes. To clarify the above explanations, we measured the amount of dyes adsorbed on $\mathrm{TiO}_{2}$ film by desorbing the dyes from the $\mathrm{TiO}_{2}$ surface with $\mathrm{KOH}$. The amounts of three dyes adsorbed on $\mathrm{TiO}_{2}$ film were measured to be $2.94 \times 10^{-7}, 3.02 \times 10^{-7}$, and $3.76 \times$ $10^{-7} \mathrm{mmol} \mathrm{cm}^{-2}$ for $\mathrm{JJ}-7, \mathrm{JJ}-9$, and $\mathbf{N 7 1 9}$, respectively. The low adsorption of JJ-7 and JJ-9 can be due to the presence of bulky protecting groups with electron withdrawing abilities of tetra-substituted ammonium groups and the electrostatic repulsion of negatively charged carboxylic groups.

The electrochemical properties of the two sensitizers JJ7 and JJ-9 were studied by cyclic voltammetry in $\mathrm{CH}_{3} \mathrm{CN}$ with $0.1 \mathrm{M}$ tetrabutylammonium hexafluorophosphate using $\mathrm{TiO}_{2}$ film with adsorbed dyes as working electrode. The oxidation potentials of JJ-7 and JJ-9 adsorbed on $\mathrm{TiO}_{2}$ film show quasi-reversible couples at $1.07 \mathrm{~V}$ and $1.03 \mathrm{~V}$ versus NHE, respectively (Table 1 ). The $\mathrm{Ru}^{\mathrm{III} / \mathrm{II}}$ oxidation potentials of JJ-7 and JJ-9 are more positive than that of N719. The HOMO-LUMO energy band gaps $\left(E_{0-0}\right)$ of JJ-7 and JJ-9 determined from the intersection of absorption and emission spectra are 2.08 and $2.06 \mathrm{eV}$, respectively, more increased than that of N719 (1.85 eV for experimental calculation [25] and $1.97 \mathrm{eV}$ for theoretical calculation by B3LYP/3-21 G [26, 27]). This reflects the increased electron withdrawing properties of ligand with tetra-substituted ammonium groups. The reduction potentials of two dyes calculated from the oxidation potentials and the $E_{0-0}$ determined from the intersection of absorption and emission spectra are $-1.01 \mathrm{~V}$ for $\mathrm{JJ}-7$ and $-1.03 \mathrm{~V}$ for JJ-9 versus NHE. A negative shift in the reduction potential of JJ-7 and JJ-9 compared to N719 is attributable to electron-withdrawing abilities in ligands and increased HOMO-LUMO energy band gaps.

Figure 7 shows intensity of radiation in dye-sensitized solar cell using JJ-7 and N719 sensitizers. After making box, we have measured the intensity of radiation as in Figure 7. The radiation intensities for JJ-7 sensitizers with both 5 and $10 \mu \mathrm{m} \mathrm{TiO}_{2}$ thickness films are much higher than that of N719 sensitizer with $5 \mu \mathrm{m} \mathrm{TiO}$ thickness film. This result demonstrates that the novel JJ-7 sensitizer is very effective in greenhouse dye-sensitized solar cell to grow plant. On the other hand, the existing N719 sensitizer is not useful because of the low quantity of light. The different light quantity might be caused by the different molecular structure of the dyes. The high quantity of light in JJ-7 compared to that of N719 may be due to the defects of adsorption of JJ-7 sensitizer on the $\mathrm{TiO}_{2}$ electrodes.

In conclusion, two novel ruthenium bipyridyl sensitizers have been synthesized and characterized. A solar-toelectricity conversion efficiency of $4.96 \%$ (for $5 \mu \mathrm{m} \mathrm{TiO}_{2}$ film) and $6.58 \%$ (for $10 \mu \mathrm{m} \mathrm{TiO}{ }_{2}$ film) for JJ-7 is comparable to $6.25 \%$ (for $5 \mu \mathrm{m} \mathrm{TiO}_{2}$ film) and 7.67\% (for $10 \mu \mathrm{m} \mathrm{TiO}{ }_{2}$ film) for the N719-sensitized solar cell. The high transmittance $(62 \%$ at $660 \mathrm{~nm}$ and $18 \%$ at $440 \mathrm{~nm}$ ) of JJ-7 is attributed to its low absorption extinction coefficient of MLCT band in the visible region and blue-shift by an increased HOMO-LUMO energy band gap. We believe that the development of highly efficient sensitizers for greenhouse dye-sensitized solar cell is possible through meticulously molecular engineering, and work on these is now in progress.

\section{Experimental Section}

3.1. Fabrication of Dye-Sensitized Solar Cells. Fluorine-doped tin oxide (FTO) glass plates (Pilkington TEC Glass-TEC 8 , solar $2.3 \mathrm{~mm}$ thickness) were cleaned in a detergent solution using an ultrasonic bath for $30 \mathrm{~min}$ and then rinsed with water and ethanol. Then, the plates were immersed in $40 \mathrm{mM} \mathrm{TiCl}_{4}$ (aqueous) at $70^{\circ} \mathrm{C}$ for $30 \mathrm{~min}$ and washed with water and ethanol. A transparent nanocrystalline layer was prepared on the FTO glass plates by using a doctor blade printing $\mathrm{TiO}_{2}$ paste (Solaronix, Ti-Nanoxide T/SP), which was then dried for $2 \mathrm{~h}$ at $25^{\circ} \mathrm{C}$. The $\mathrm{TiO}_{2}$ electrodes were gradually heated under an air flow at $325^{\circ} \mathrm{C}$ for $5 \mathrm{~min}$, at $375^{\circ} \mathrm{C}$ for $5 \mathrm{~min}$, at $450^{\circ} \mathrm{C}$ for $15 \mathrm{~min}$, and at $500^{\circ} \mathrm{C}$ for $15 \mathrm{~min}$. The thickness of the transparent layer was measured by using an Alpha-step 250 surface profilometer (Tencor Instruments, San Jose, CA). The resulting film was composed of a 5 

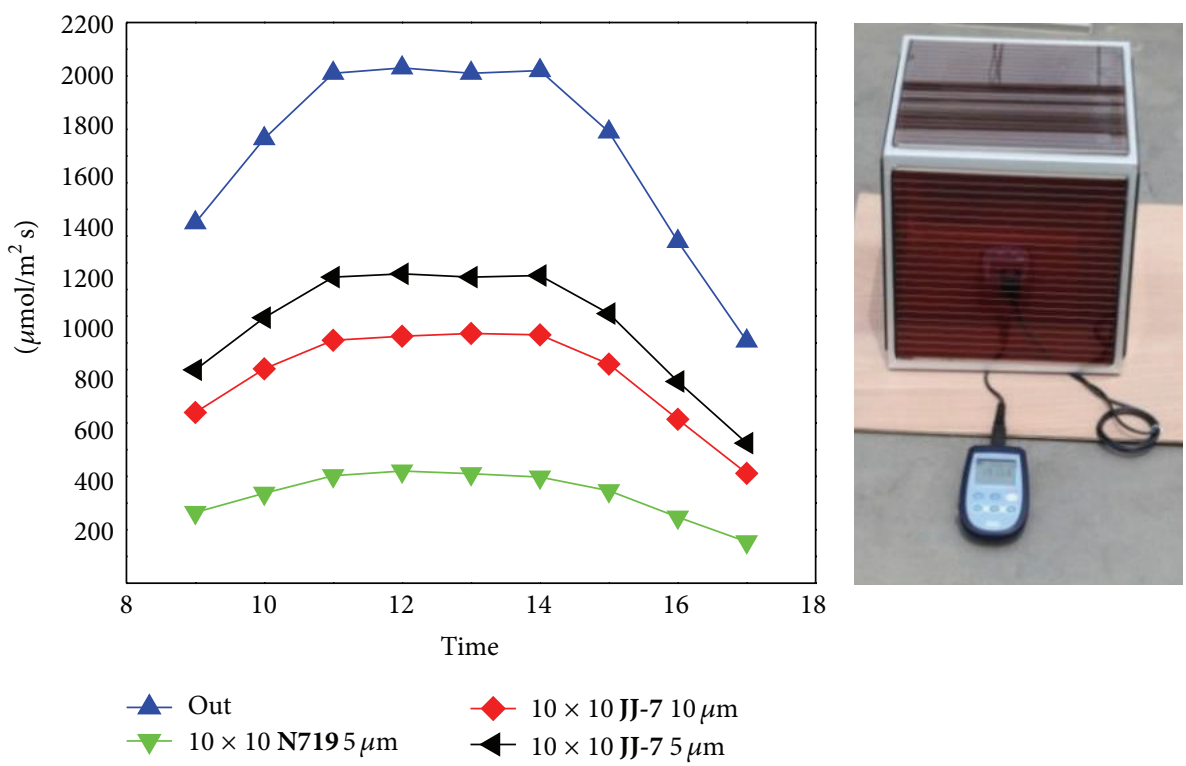

Figure 7: The intensity of radiation for JJ-7 (5 $\mu \mathrm{m}$, black line), JJ-7 (10 $\mu \mathrm{m}$, red line), N719 (5 $\mu \mathrm{m}$, green line), and out (blue line) and greenhouse test-bed of dye-sensitized solar cell using new sensitizer (JJ-7).

and $10 \mu \mathrm{m}$ thick transparent layer. The $\mathrm{TiO}_{2}$ electrodes were treated again with $\mathrm{TiCl}_{4}$ at $70^{\circ} \mathrm{C}$ for $30 \mathrm{~min}$ and sintered at $500^{\circ} \mathrm{C}$ for $30 \mathrm{~min}$. Then, they were immersed in $\mathbf{J J}-\mathbf{7}$ and $\mathbf{~ J J - 9}$ ( $0.3 \mathrm{mM}$ in ethanol) solutions and kept at room temperature for $24 \mathrm{~h}$. FTO plates for the counter electrodes were cleaned in an ultrasonic bath in $\mathrm{H}_{2} \mathrm{O}$, acetone, and $0.1 \mathrm{M}$ aqueous $\mathrm{HCl}$, subsequently. The counter electrodes were prepared by placing a drop of an $\mathrm{H}_{2} \mathrm{PtCl}_{6}$ solution $(2 \mathrm{mg} \mathrm{Pt}$ in $1 \mathrm{~mL}$ ethanol) on an FTO plate and heating it (at $400^{\circ} \mathrm{C}$ ) for $15 \mathrm{~min}$. The dye adsorbed $\mathrm{TiO}_{2}$ electrodes and the Pt counter electrodes were assembled into a sealed sandwich-type cell by heating at $80^{\circ} \mathrm{C}$ using a hot-melt ionomer film (Surlyn) as a spacer between the electrodes. A drop of the electrolyte consisting of $0.6 \mathrm{M}$ 1,2-dimethyl-3-propylimidazolium iodide (DMPII), 0.05 $\mathrm{M} \mathrm{I}_{2}, 0.1 \mathrm{M} \mathrm{LiI}$, and $0.5 \mathrm{M}$ tert-butylpyridine in acetonitrile was placed in the drilled hole of the counter electrode and was driven into the cell via vacuum backfilling. Finally, the hole was sealed using additional Surlyn and a cover glass (0.1 mm thickness).

\subsection{Typical Procedures and Analytical Data}

JJ-7 Complex. A mixture of N3 (100 mg, $0.141 \mathrm{mmol}$ ) and trimethylphenylammonium hydroxide (434 mg, $0.708 \mathrm{mmol})$ in $\mathrm{MeOH}(2 \mathrm{~mL})$ was stirred at room temperature for $2 \mathrm{~h}$. The pure product $\mathrm{JJ}-7$ was obtained by Sephadex LH-20 column with methanol as eluent. Yield: 97\%. ${ }^{1} \mathrm{H}$ NMR (CD $\left.\mathrm{OD}\right): 9.43$ (d, 2H, $\left.J=5.7 \mathrm{~Hz}\right), 8.90$ $(\mathrm{s}, 2 \mathrm{H}), 8.74(\mathrm{~s}, 2 \mathrm{H}), 8.13(\mathrm{dd}, 2 \mathrm{H}, J=5.7 \mathrm{~Hz}), 7.93(\mathrm{~m}$, $6 \mathrm{H})$, 7.63-7.50 (m, 18H, $3.70(\mathrm{~s}, 36 \mathrm{H})$. Anal. calcd for $\mathrm{C}_{62} \mathrm{H}_{68} \mathrm{~N}_{10} \mathrm{O}_{8} \mathrm{RuS}_{2}$ : C, 59.74; H, 5.50. Found: C, 59.77; $\mathrm{H}, 5.48$.

JJ-9 Complex. A mixture of N3 (100 mg, $0.141 \mathrm{mmol}$ ) and benzyltrimethylammonium hydroxide (296 mg,
$0.708 \mathrm{mmol})$ in $\mathrm{MeOH}(2 \mathrm{~mL})$ was stirred at room temperature for $2 \mathrm{~h}$. The pure product JJ-9 was obtained by Sephadex LH-20 column with methanol as eluent. Yield: $94 \% .{ }^{1} \mathrm{H}$ NMR (CD 3 OD): $9.41(\mathrm{~d}, 2 \mathrm{H}, J=5.8 \mathrm{~Hz}), 8.91(\mathrm{~s}, 2 \mathrm{H}), 8.75$ (s, 2H), $8.10(\mathrm{dd}, 2 \mathrm{H}, J=5.8 \mathrm{~Hz}), 7.54(\mathrm{~m}, 24 \mathrm{H}), 4.55(\mathrm{~s}, 8 \mathrm{H})$, $3.12(\mathrm{~s}, 36 \mathrm{H})$. Anal. calcd for $\mathrm{C}_{66} \mathrm{H}_{76} \mathrm{~N}_{10} \mathrm{O}_{8} \mathrm{RuS}_{2}$ : C, 60.86; $\mathrm{H}$, 5.88. Found: C, 60.78; H, 5.94 .

\section{Conflict of Interests}

The authors declare that there is no conflict of interests regarding the publication of this paper.

\section{Acknowledgment}

This work was supported by Electronics and Telecommunications Research Institute (ETRI).

\section{References}

[1] B. O’Regan and M. Grätzel, "A low-cost, high-efficiency solar cell based on dye-sensitized colloidal $\mathrm{TiO}_{2}$ films," Nature, vol. 353, pp. 737-740, 1991.

[2] K. Hara, H. Sugihara, Y. Tachibana et al., "Dye-sensitized nanocrystalline $\mathrm{TiO}_{2}$ solar cells based on ruthenium(II) phenanthroline complex photosensitizers," Langmuir, vol. 17, no. 19, pp. 5992-5999, 2001.

[3] T. Horiuchi, H. Miura, K. Sumioka, and S. Uchida, "High efficiency of dye-sensitized solar cells based on metal-free indoline dyes," Journal of the American Chemical Society, vol. 126, no. 39, pp. 12218-12219, 2004.

[4] S. A. Haque, S. Handa, K. Peter, E. Palomares, M. Thelakkat, and J. R. Durrant, "Supermolecular control of charge transfer in dyesensitized Nanocrystalline $\mathrm{TiO}_{2}$ films: towards a quantitative 
structure-function relationship," Angewandte Chemie International Edition, vol. 44, no. 35, pp. 5740-5744, 2005.

[5] D. Kuang, P. Walter, F. Nuesch et al., "Co-sensitization of organic dyes for efficient ionic liquid electrolyte-based dye-sensitized solar cells," Langmuir, vol. 23, no. 22, pp. 10906-10909, 2007.

[6] T. Renouard, R. A. Fallahpour, M. K. Nazeeruddin et al., "Novel ruthenium sensitizers containing functionalized hybrid tetradentate ligands: Synthesis, characterization, and INDO/S analysis," Inorganic Chemistry, vol. 41, no. 2, pp. 367-378, 2002.

[7] M. K. Nazeeruddin, P. Péchy, T. Renouard et al., "Engineering of efficient panchromatic sensitizers for nanocrystalline $\mathrm{TiO}_{2}$ based solar cells," Journal of the American Chemical Society, vol. 123, no. 8, pp. 1613-1624, 2001.

[8] K. Chen, Y.-H. Hong, Y. Chi, W.-H. Liu, B.-S. Chen, and P.-T. Chou, "Strategic design and synthesis of novel tridentate bipyridine pyrazolate coupled $\mathrm{Ru}(\mathrm{II})$ complexes to achieve superior solar conversion efficiency," Journal of Materials Chemistry, vol. 19, no. 30, pp. 5329-5335, 2009.

[9] S. Pearson, A. E. Wheldon, and P. Hadley, "Radiation transmission and fluorescence of nine greenhouse cladding materials," Journal of Agricultural Engineering Research, vol. 62, no. 1, pp. 61-70, 1995.

[10] C. Kittas and A. Baille, "Determination of the spectral properties of several greenhouse cover materials and evaluation of specific parameters related to plant response," Journal of Agricultural Engineering Research, vol. 71, no. 2, pp. 193-202, 1998.

[11] S. Tazawa, "Effects of various radiant sources on plant growth (part 1)," Japan Agricultural Research Quarterly, vol. 33, p. 163, 1999.

[12] S. Hemming, E. van Os, A. Dieleman et al., "Possibilities of increasing production and quality of strawberry fruits and several flowers by new blue fluorescent greenhouse films," Acta Horticulturae, vol. 691, pp. 225-232, 2005.

[13] E. Espí, A. Salmerón, A. Fontecha, Y. García, and A. I. Real, "Plastic films for agricultural applications," Journal of Plastic Film and Sheeting, vol. 22, no. 2, pp. 85-102, 2006.

[14] W. Fang and R. C. Jao, Transplant Production in the 21st Century, 2000.

[15] R. Moe, S. O. Grimstad, and H. R. Gislerød, "The use of artificial light in year round production of greenhouse crops in Norway," Acta Horticulturae, vol. 711, pp. 35-42, 2006.

[16] H.-H. Kim, R. M. Wheeler, J. C. Sager, N. C. Yorio, and G. D. Goins, "Light-emitting diodes as an illumination source for plants: a review of research at Kennedy Space Center," Habitation, vol. 10, no. 2, pp. 71-78, 2005.

[17] E. Ono and H. Watanabe, "Plant factories blossom," Resource: Engineering \& Technology for Sustainable World, vol. 13, no. 2, pp. 13-14, 2006.

[18] R. C. Morrow, "LED lighting in horticulture," HortScience, vol. 43, no. 7, pp. 1947-1950, 2008.

[19] G. D. Massa, H. H. Kim, R. M. Wheeler, and C. A. Mitchell, "Plant productivity in response to LED lighting," HortScience, vol. 43, no. 7, pp. 1951-1956, 2008.

[20] N. Yeh and J.-P. Chung, "High-brightness LEDs-energy efficient lighting sources and their potential in indoor plant cultivation," Renewable and Sustainable Energy Reviews, vol. 13, no. 8, pp. 2175-2180, 2009.

[21] I. Vänninen, D. M. Pinto, A. I. Nissinen, N. S. Johansen, and L. Shipp, "In the light of new greenhouse technologies: 1. Plantmediated effects of artificial lighting on arthropods and tritrophic interactions," Annals of Applied Biology, vol. 157, no. 3, pp. 393-414, 2010.
[22] T. Bessho, E. Yoneda, J.-H. Yum et al., "New paradigm in molecular engineering of sensitizers for solar cell applications," Journal of the American Chemical Society, vol. 131, no. 16, pp. 5930-5934, 2009.

[23] F. Mater, T. H. Ghaddar, K. Walley, T. DosSantos, J. R. Durrant, and B. O'Regan, "A new ruthenium polypyridyl dye, TG6, whose performance in dye-sensitized solar cells is surprisingly close to that of N719, the 'dye to beat' for 17 years ," Journal of Materials Chemistry, vol. 18, pp. 4246-4253, 2008.

[24] M. K. Nazeeruddin, R. Humphry-Baker, P. Liska, and M. Grätzel, "Investigation of sensitizer adsorption and the influence of protons on current and voltage of a dye-sensitized nanocrystalline $\mathrm{TiO}_{2}$ solar cell," The Journal of Physical Chemistry B, vol. 107, no. 34, pp. 8981-8987, 2003.

[25] Y. Lee, S. R. Jang, R. Vittal, and K. J. Kim, "Dinuclear Ru(II) dyes for improved performance of dye-sensitized $\mathrm{TiO}_{2}$ solar cells," New Journal of Chemistry, vol. 31, no. 12, pp. 2120-2126, 2007.

[26] M. K. Nazeeruddin, F. De Angelis, S. Fantacci et al., "Combined experimental and DFT-TDDFT computational study of photoelectrochemical cell ruthenium sensitizers," Journal of the American Chemical Society, vol. 127, no. 48, pp. 16835-16847, 2005.

[27] M. K. Nazeeruddin, T. Bessho, L. Cevey et al., "A high molar extinction coefficient charge transfer sensitizer and its application in dye-sensitized solar cell," Journal of Photochemistry and Photobiology A: Chemistry, vol. 185, no. 2-3, pp. 331-337, 2007. 

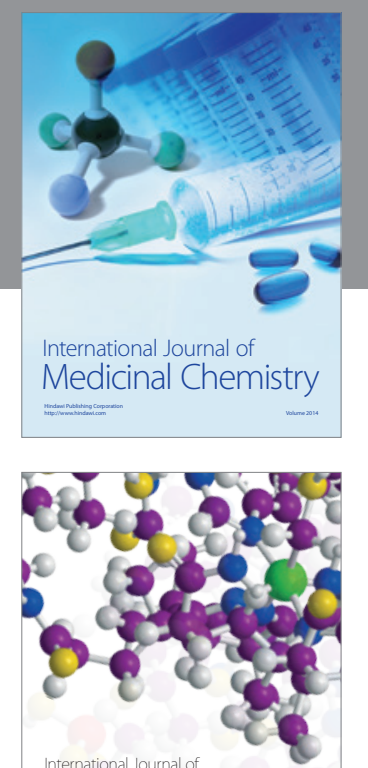

\section{Carbohydrate} Chemistry

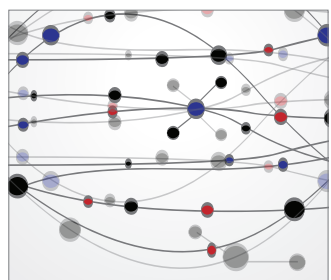

The Scientific World Journal
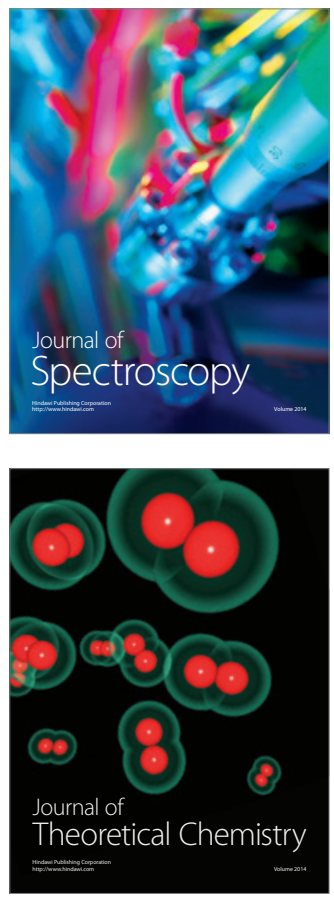
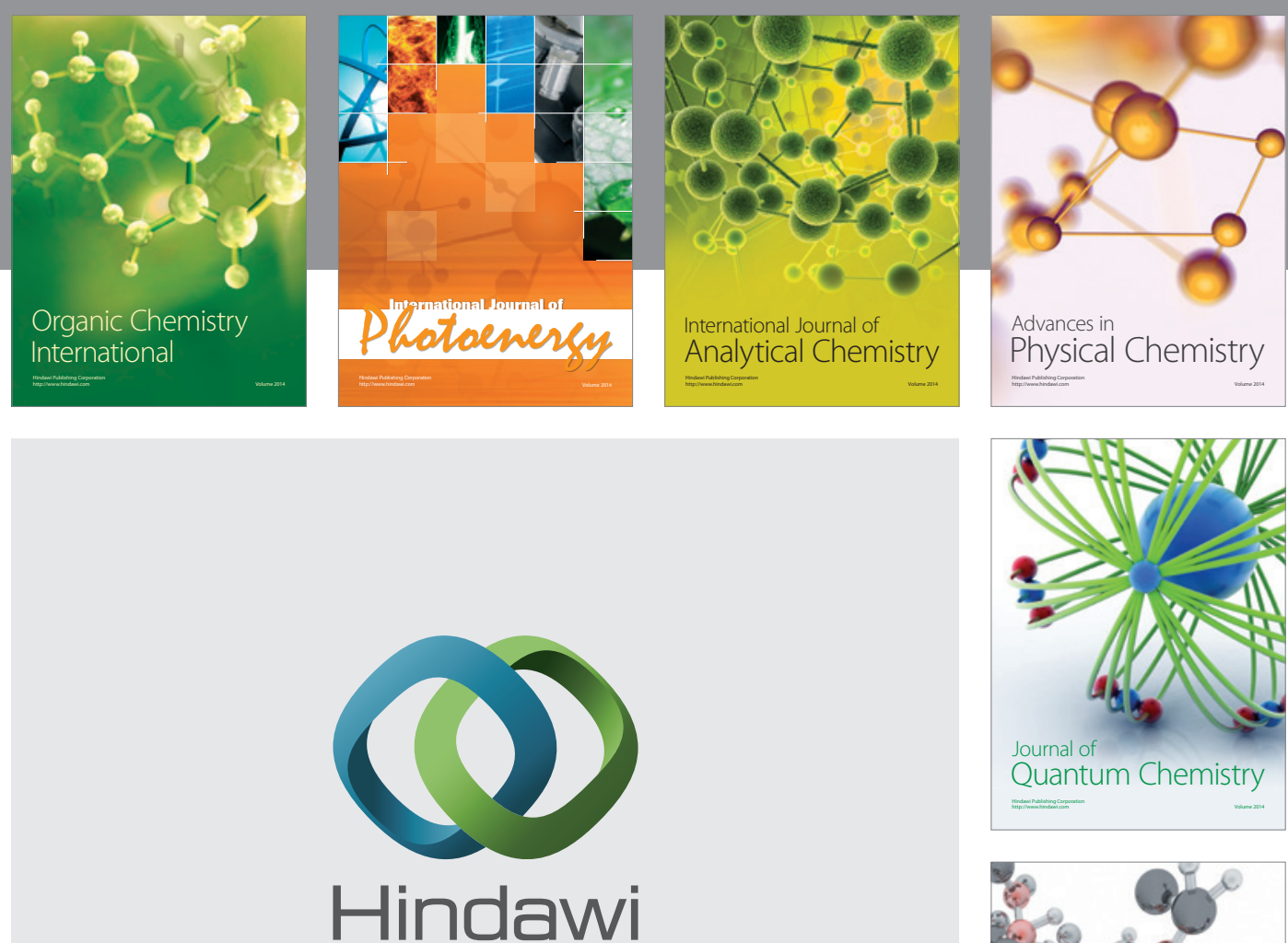

Submit your manuscripts at

http://www.hindawi.com

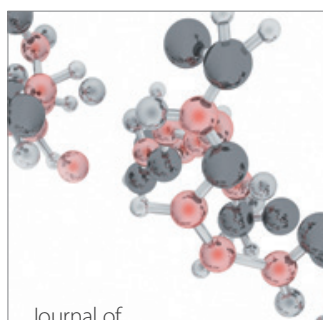

Analytical Methods

in Chemistry

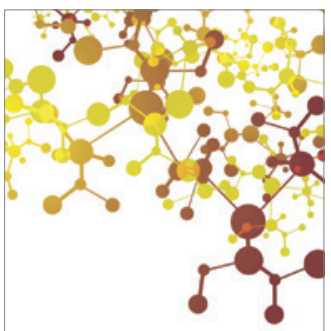

Journal of

Applied Chemistry

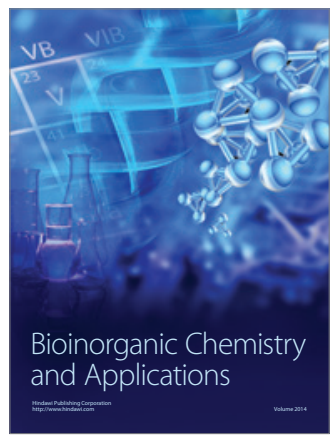

Inorganic Chemistry
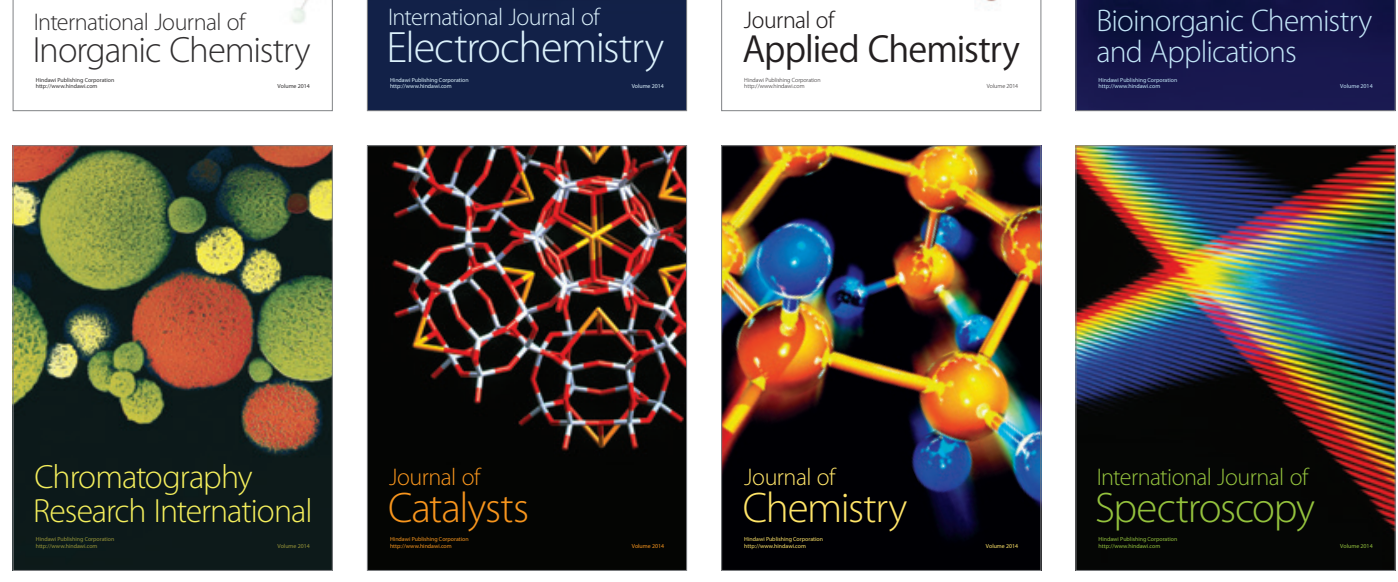